\title{
PROSES PADU SERASI DALAM PENGEMBANGAN KAWASAN PESISIR KOTA SEMARANG
}

\author{
Mohammad Agung Ridlo ${ }^{1}$ \\ Eppy Yuliani ${ }^{2}$ \\ Program Studi Perencanaan Wilayah dan Kota Fakultas Teknik Universitas Islam Sultan Agung ${ }^{1,2}$ \\ Penulis Korespondensi e-mail: agungridlo@gmail.com
}

\begin{abstract}
In almost all regions of the Coastal Indonesia conflicts often occur with various interests. The main cause of this problem (conflict) is spatial planning that does not / does not pay attention to Coastal Resources in the region. This happens one of them as information that needs to be used. Various parties have an interest in their own goals, objectives and plans for exploiting the Coastal Resources. Likewise, the City of Semarang, in developing Coastal / Coastal areas, should ask permission from the holder of a fixed land right or at least leave a small amount of space from the front area of Semarang City as a public open space. Semarang City is a city that is very poor in public space. In the management of the Coastal area it is necessary to have direction in this Coastal area as a public space, not a free trade process with profit-oriented goals. But still giving access to the free space of the beach that can be entered by permitted. Free space can be realized by giving a certain free distance from the coastline. Therefore, the combination of spatial plans and zoning plans is needed. In the process of regional spatial planning (RTRW) and zoning plans (RZ) of Coastal areas, it is necessary to make a harmonious process.
\end{abstract}

Key Words: Mix and Match, Development, Coastal Areas

\begin{abstract}
ABSTRAK
Kawasan pesisir menjadi kawasan yang mengalami berbagai permasalahan dari berbagai sudut kepentingan. Penataan ruang pada kawasan pesisir yang belum dapat selaras dengan potensi sumberdaya pesisir, menjadi salah satu alasan dari munculnya berbagai permasalahan yang ada. Tidak satupadunya tujuan, target dan rencana dalam pengelolaan sumberdaya pesisir membuat penataan kawasan pesisir kurang menyatu. Demikian pula halnya dengan Kota Semarang, dalam mengembangkan kawasan pesisir/pantai semestinya berwenang mengingatkan para pemegang izin/hak guna lahan untuk tetap menjadikan atau minimal menyisakan sedikit ruang dari kawasan terdepan (muka) Kota Semarang ini sebagai ruang terbuka publik. Kota Semarang merupakan kota yang sangat miskin akan ruang publik. Dalam pengelolaan kawasan pesisir perlu adanya pengarahan bahwa kawasan pesisir ini sebagai ruang publik, tidak sekedar suatu proses dagang semata dengan tujuan profit oriented. Namun tetap memberikan akses ke ruang bebas dari pantai yang dapat dimasuki oleh siapapun. Ruang bebas dapat diwujudkan dengan memberikan jarak bebas tertentu dari garis pantai. Oleh karenanya, maka perpaduan rencana tata ruang darat dan rencana zonasi pesisir sangat diperlukan. Dalam proses penyusunan rencana tata ruang wilayah (RTRW) dan rencana zonasi (RZ) wilayah pesisir, perlu dilakukan proses padu serasi.

Kata Kunci: Padu Serasi, Pengembangan, Kawasan Pesisir
\end{abstract}




\section{PENDAHULUAN}

Kurangnya perhatian dalam penataan ruang yang hampir terjadi di seluruh kawasan pesisir Indonesia mengakibatkan munculnya permasalahan atau konflik dengan berbagai kepentingan. Permasalahan yang terjadi disebabkan kurangnya informasi dalam penggunaan sumber daya pesisir secara terpadu dan efisien, sehingga banyak pihak yang memiliki tujuan atau target utama dalam mengeksploitasi sumber daya pesisir yang ada (Ridlo dan Eppy, 2018). Berbagai aktivitas bermunculan di wilayah pesisir seperti kegiatan usaha perikanan, perindustrian, permukiman, reklamasi pantai, obyek wisata dan kegiatan ekonomi lainnya. (Constanza, et.al, 1997). Muncul permasalahan seperti terjadinya pencemaran lingkungan, overeksploitasi sumberdaya alam, perusakan fisik habitat pesisir terutama mangrove dan terumbu karang, terjadinya abrasi dan sedimentasi akibat modifikasi land-scape dan seascape (seperti reklamasi, pembangunan jetty, dan lain-lain) yang tidak sesuai dengan karakteristik dan dinamika alam serta adanya Dualistic economy, yang 65\% penduduk pesisir tergolong miskin.

Kedepan pembangunan kawasan pesisir untuk menjawab Kebutuhan penyediaan lahan bagi perkembangan kota memang tidak bisa dielakkan. Seperti pengembangan permukiman, lokasi perindustrian, pelabuhan, dan fasilitas sosial lainnya seperti pusat perdagangan, hiburan, dan wisata. Pengembangan wilayah ke arah laut dengan cara reklamasi memang menjadi alternatif yang paling menjanjikan. Pertumbuhan kota pantai tidak dapat lagi dilakukan ke arah darat khususnya pada kawasan pesisir dengan landscape pegunungan seperti Manado, Balikpapan, dan Batam. Seperti halnya Jakarta dan Surabaya, kawasan pesisir dengan kepadatan penduduk dan intensitas pembangunan sudah sangat tinggi. Alternatifnya memang reklamasi sebagai salah satu solusi penataan kota pantai, karena status lahannya relatif aman, secara legal perairan pesisir dikuasai oleh Negara.

Beberapa daerah telah merencanakan atau melaksanakan kegiatan reklamasi wilayah pesisir, seperti Jakarta, Surabaya, Semarang, Manado, Makasar, Balikpapan, Bali, Lampung, dan lain-lain. Namun kegiatan reklamasi dilaksanakan dengan landasan peraturan dan cara yang berbeda-beda, karena belum ada peraturan dan pedoman secara nasional. Sehingga sebagian besar kegiatan reklamasi menghadapi permasalahan sosial dan lingkungan.

Dampak negatif yang terjadi sebagai akibat perubahan kondisi ekosistem pesisir berkaitan dengan perubahan hidrodinamika pesisir. Hal ini mengakibatkan abrasi atau 
sedimentasi dan Peningkatan kemungkinan banjir. (Ridlo dan Gata, 2014). Selain itu juga tingkat kesejahteraan masyarakat masih belum baik tercermin pada masih banyaknya slum settlement dan squatters settlement (Ridlo, 2011).

\section{METODOLOGI}

Metodologi kualitatif rasionalistik menjadi metodologi dalam penelitian ini, dengan beberapa alat analisis pendekatan seperti pendekatan administratif dan pendekatan pembangunan berwawasan lingkungan dan berkelanjutan. Pendekatan administratif berupa review perundangan yang berlaku terkait kawasan pesisir seperti undang-undang Penataan Ruang dan Pengelolaan Wilayah Pesisir dan Pulau-Pulau Kecil. Sedangkan pada pendekatan pembangunan berwawasan lingkungan dan berkelanjutan merupakan upaya pendekatan dengan melihat kondisi secara kritis dalam memandang permasalahan yang berdasarkan aspek nilai lingkungan dan berkelanjutan.

\section{HASIL DAN PEMBAHASAN}

\subsection{Kawasan Pesisir di Kota Semarang}

Menurut Ridlo (2015), Kota Semarang merupakan suatu kota yang mengalami perkembangan ke semua arah sehingga dengan perkembangan tersebut mengakibatkan lahan menjadi sempit dan kebutuhan akan lahan menjadi sulit terpenuhi. Permasalahan tersebut mengarah juga ke kawasan pesisir. Upaya yang dilakukan dalam mencukupi kebutuhan lahan untuk berbagai kegiatan meliputi pengurugan rawa-rawa, pengeprasan perbukitan, serta mereklamasi pantai. Berdasarkan pernyataan diatas maka perlunya mengkaji secara ekologis dalam penataan pembangunan kawasan pesisir.

Luasan dari kawasan pesisir yang ada di Kota Semarang sebesar 5.039,17 Ha atau 0,02\% dari 37.366.838 Ha besar luasan total Kota Semarang. Panjang Kota Semarang \pm 25 Km yang meliputi Semarang Utara 5,56 Km, Semarang Barat 8,94 Km, Kecamatan Tugu sepanjang 3,5 Km, dan Genuk $7 \mathrm{Km}$. Kawasan pesisir ini sebanyak 17 kelurahan di 6 kecamatang yaitu meliputi Kelurahan Mangkang Kulon, Kelurahan Kemijen, Kelurahan Tambakrejo, Kelurahan Trimulyo, Kelurahan Mangundharjo, Kelurahan Terboyo Kulon, Kelurahan Terboyo Wetan, Kelurahan Panggung Lor, Kelurahan Randugarut, Kelurahan Trimulyo, Kelurahan Mangkang Wetan, Kelurahan Tawangsari, Kelurahan Jrakah, Kelurahan Tuguredjo, Kelurahan Tanjungmas, Kelurahan Bandarhardjo, dan Kelurahan 
Karanganyar. Terjaid kompetisi dari berbagai kelompok/golongan antara "the have" sampai "have nots" di Kawasan Pesisir, sehingga dari kompetisi tersebut tampak potensi dan peluang yang besar dalam mengembangkan kawasan pesisir yang dilaksanakan oleh golongan "the have" atau pihak pengembang swasta (Ridlo, 2016).

Jika ditelusuri, hampir sepanjang pantai Utara Kota Semarang sudah dikuasai dan dikapling-kapling oleh pihak swasta. Kawasan tersebut memang merupakan kawasan yang strategis untuk dikembangkan sebagai kawasan taman rekreasi maupun perumahan mewah. Dapat dipastikan bahwa tidak semua warga kota dapat mengakses masuk ke kawasan tersebut, hanya orang-orang yang mampu membeli rumah/kapling saja. Sehingga tidak sedikit pun ruang tersisa untuk dinikmati warga kota secara gratis.

Mungkin warga kota telah lupa dan perlu saling mengingatkan bahwa kawasan pantai itu merupakan bagian dari ruang terbuka umum kota (public open-space). Dengan begitu pantai seharusnya memiliki kemudahan akses bagi seluruh warga kota. Akan tetapi, selama ini ternyata kita harus membayar untuk menikmati alam tepi pantai, semisal masuk kawasan Pantai Marina di Semarang Utara. Kondisi seperti itu setidaknya menyebabkan sebagian warga kota mulai lupa bahwa Semarang adalah kota pantai (waterfront-city).

Hal ini menimbulkan pertanyaan: apakah tidak ada kontrol maupun arahan dari pihak Pemerintah Kota Semarang dalam mengembangkan kawasan pantai sebagai ruang publik? Semestinya Pemerintah Kota Semarang berwenang dalam mengingatkan para pemegang izin/hak guna lahan untuk tetap menjadikan atau minimal menyisakan sedikit ruang dari kawasan terdepan (muka) Kota Semarang ini sebagai ruang terbuka publik. Semarang merupakan kota yang sangat miskin akan ruang publik. (Ridlo dan Eppy, 2018). Apakah warga Semarang sendiri sadar bahwa hak mereka untuk menikmati ruang publik hampir tidak ada?.

Wilayah pesisir sangat luas sekali. Karena itu dalam pengelolaan wilayah pesisir digunakan 3 bentuk dari batasan pada wilayah pesisir, diantaranya:

- Menggunakan pendekatan ekologis: terdapatnya proses-proses kelautan seperti intrusi air laut dan pasang surut yang mempengaruhi kawasan daratan. Selain itu juga terdapat proses-proses daratan yang meliputi sedimentasi dan pencemaran yang mempengaruhi kawasan laut dimana kedua peoses ini menjadi bagian dari wilayah pesisir. 
- Menggunakan pendekatan administratif: Wilayah pesisir yaitu wilayah yang memiliki pendekatan mengacu terhadap batasan terluar dari wilayah yang secara administratif berada disamping hulu dari kecamatan atau kabupaten/kota yang memiliki laut. Selain itu juga, batasan 12 mil dari garis pantai pada propinsi atau sepertiganya pada kabupaten/kota ke arah laut.

- Menggunakan pendekatan perencanaan: Pada pendekatan ini wilayah pesisir mengacu kepada wilayah yang memfokuskan pada penanganan issue yang pengelolaannya secara bertanggungjawab dalam melakukan perencanaan terhadap pengelolaan sumberdaya yang ada. Misalnya batas pengelolaan budidaya mutiara adalah wilayah perairan yang diperuntukkan bagi sarana pemeliharaan dan daerah penyangga sekelilingnya.

\subsection{Batas Wilayah Pesisir}

Sebelumnya wilayah peisisr belum memiliki pengertian yang baku. Tetapi berdasarkan kesepakatan umum di dunia dalam mengartikan wilayah pesisir (Coastal Zone) sebagai wilayah peralihan antara lautan dan daratan, dengan batas dari wilayah pesisir bagian daratan yaitu jarak secara arbitrer dari rata-rata pasang tinggi (mean high tide), namun batas wialayah pesisir ke arah laut yaitu batas yurisdiksi wilayah provinsi (state) pada suatu negara (Dahuri, dkk., 1996).

Wilayah pesisir merupakan wilayah pertemuan antara laut dan darat, dengan batasan ke arah laut yang terjadi di bagian laut yang mendapat pengaruh dari proses alami yang terdapat di darat meliputi seperti sedimentasi dan aliran air tawar, maupun yang disebabkan karena kegiatan manusia di darat, seperti penggundulan hutan, pertanian dan pencemaran. Sedangkan batasan ke arah darat meliputi bagian daratan baik kering maupun terendam air, yang masih dipengaruhi oleh sifat-sifat laut, seperti pasang surut, angin laut, dan perembesan air asin.. (Beatly, 1994; Dahuri, dkk., 1996).

Berdasarkan uraian diatas menunjukan bahwa sebenarnya garis batas dari wilayah pesisir ridak ada yang secara konkrit. Batas dari wilayah pantai didapatkan dari penentuan kondisi dan karakteristik pesisir setempat yang letaknya didasarkan pada garis imajiner. Garis batas ini berada jauh dari garis pantai, letaknya pada wilayah pesisir yang landau dengan sungai besar. Namun pantai yang curam yang berbatasan langsung dengan laut dalam memiliki wilayah peisisr yang relative sempit

Hubungan erat terjadi antara kondisi suatu wilayah dengan sistem sungai yang 
bermuara pada wialayah tersebut, Secara ekologis, wilayah pesisir dipengaruhi oleh kemungkinan terjadinya perubahan sifat sungai karena proses alami ataupun dari kegiatan manusia baik di daerah hulu maupun di hilir, sehingga secara alami wilayah pesisir menjadi bagian yang tidak terpisahkan dari Daerah Aliran Sungai (DAS).

Menurut pendapat dari pakar ilmu sosial bahwa wilayah pesisir tidak terlepas dari masyarakat pesisir dan administrasi pemerintahan dengan permasalahan sosial-ekonomi yang terjadi di wilayahnya. Potensi sumberdaya mempengaruhi kehidupan masyarakat wilayah pesisir terutama para nelayan, walaupun banyak permukiman nelayan berada jauh dari laut sehingga pengaruh laut tidak langsung mempengaruhi desa para nelayan tersebut. Oleh karena itu, menurut para nelayan kurang menyetujui dengan penetapan batas wilayah pesisir yang berdasarkan atas pengaruh dari pendekatan biologi, pendekatan geologi, dan pendekatan fisika pada pesisir saja. Di sisi lain mereka membuat batasan wilayah pesisir jauh ke arah darat yang tidak sampai ke permukiman, namun masih meluas hingga ke tempat dimana mata pencaharian penduduk yang masih memiliki hubungan dengan pemanfaatan potensi sumberdaya kelautan.

Brahtz (1972) mengemukakan pendapat bahwa dengan adanya perkembangan dari sarana dan prasarana transportasi dapat membawa semua hasil produk-produk dari sumberdaya kelautan bisa sampai ke daerah pegunungan oleh karenanya pernyataan ini membawa pernyataan bahwa wilayah pesisir ke arah darat dapat menjangkau hingga ke daerah pegunungan. Namun, apabila dikaitkan dengan sumberdaya dan lingkungan dari wilayah pesisir akan lebih luas lagi cakupannya, dikarenakan wilayah pesisir memiliki permasalahan yang kompleks yaitu baik dari aspek soial, aspek ekonomi, dan aspek kebudayaan disisi lain aspek budaya, aspek politik masyarakat akan ikut terlibat didalamnya,

Apabila kegiatan manusia menimbulkan dampak secara nyata berupa sumberdaya dan lingkungan hingga pada bagian hilir, maka demi kepentingan dari perencanaan/pengelolaan batas wilayah pesisir ke arah darat bisa sampai pada hulu daerah aliran sungai. Batasan ini cenderung menyesuaikan dari batas yuridiksi suatu wilayah negara bagian atau propinsi (Dahuri, dkk, 1996)

Menurut Hinrichson (1998) batas wilayah pesisir ke arah darat yaitu $150 \mathrm{~km}$ dari garis pantai, sedangkan menurut Carl Lundin - World Bank (1996) batas wilayah pesisir ke arah darat yaitu $50 \mathrm{~km}$ dari garis pantai. Mereka berdua sepakat bahwa batas yurisdiksi wilayah 
negara bagian atau propinsi digunakan ke arah laut.

Berdasarkan pendapat dari Beatley, et. al (1994) bahwa kesepakatan internasional, definisi dari wilayah pesisir yaitu wilayah peralihan antara laut dan daratan, dimana pengaruh percikan air laut atau pasang surut sampai mengarah ke arah darat dan ke arah laut berupa daerah paparan benua. Peernyataan ini dapat dilihat pada diagaram di bawah.

Pada tanggal 1-3 Agustus 1994 yang berlangsung di Manado terjadi rapat kerja nasional Proyek MREP (Marine Resource Evaluation and Planning), yang dikoordinasikan oleh Ditjen Pembangunan Daerah Depdagri, telah ditetapkan bahwa batas wilayah pesisir ke arah laut adalah sesuai dengan batas laut yang terdapat dalam peta lingkungan pantai Indonesia dengan skala 1:500.000; yang diterbitkan oleh Bakosurtanal (Badan Koordinasi Survey dan Pemetaan Nasional) pada tahun 1994, sedangkan ke arah darat adalah mencakup batas administratif seluruh desa atau kecamatan pantai (Dahuri, dkk., 1996).

Pada berbagai versi penetapan batas wilayah pesisir tersebut, dapat diambil beberapa hikmah meliputi:

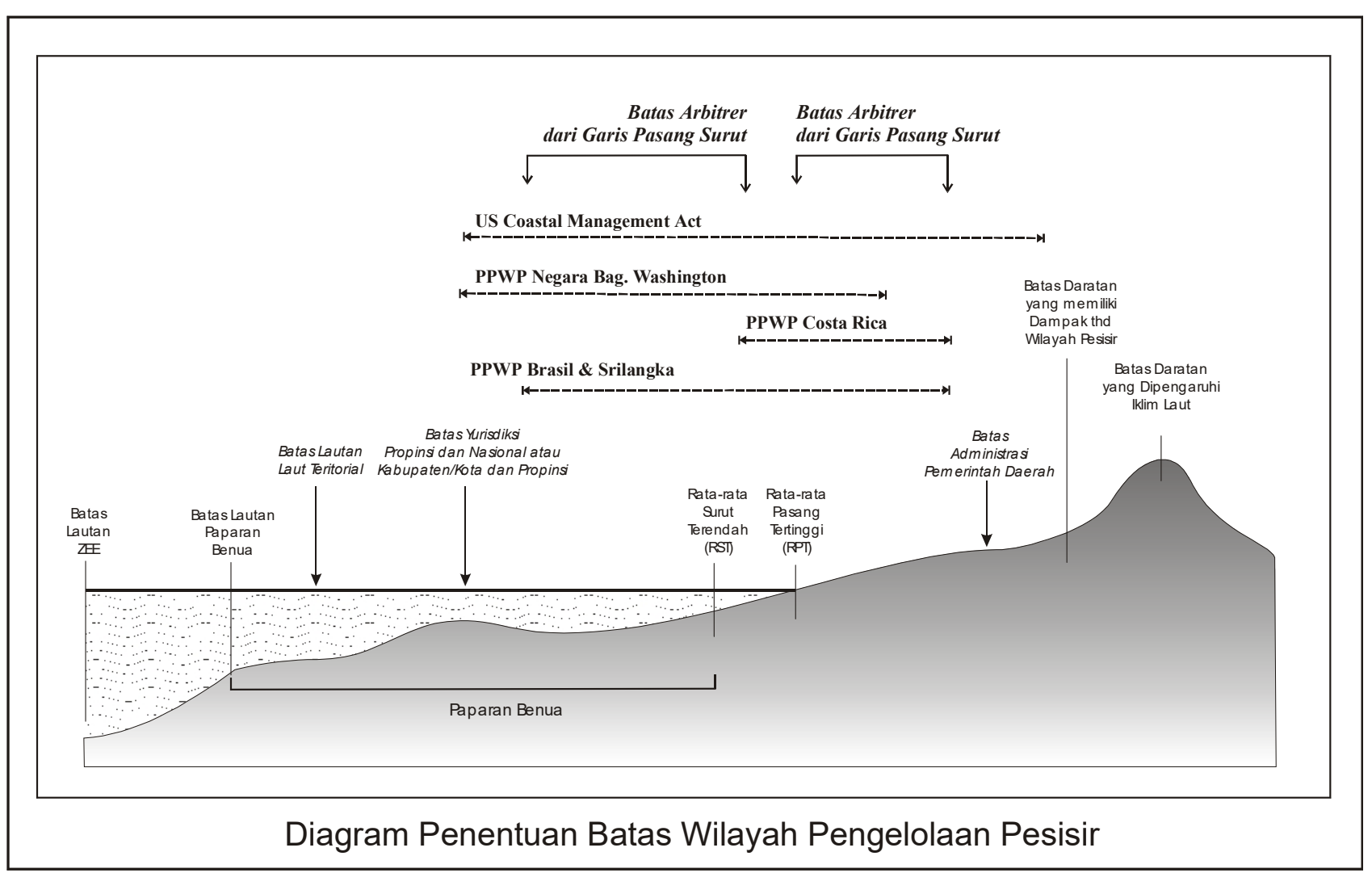

Gambar 1. Penentuan Batas Wilayah Pengelolaan Pesisisr

Sumber: Beatley et. al., 1994. 
- Batas juridiksi provinsi umumnya sesuai dengan jarak secara arbiter dari rata-rata pasang tinggi (mean high tide), dan batas ke arah laut yaitu disebut dengan batas wilayah pesisir ke arah darat (Dahuri, dkk., 1996).

- Terdapat 2 macam penetapan dari batas ke arah darat wilayah pesisir yang mendasari kepentingan pengelolaan yaitu batas untuk wilayah perencanaan (planning zone) dan batas untuk pengelolaan keseharian (day-to-day management) atau wilayah pengaturan (regulation zone).

- Apabila kegiatan pembangunan menimbulkan dampak secara nyata (significant) berupa sumberdaya dan lingkungan di wilayah pesisir, maka demi kepentingan dari perencanan (planning zone) batas wilayah pesisir ke arah darat bisa sampai jauh ke hulu. Berdasarkan pernyataan ini maka wilayah perencanaan sebaiknya mencakup seluruh daerah daratan atau hulu.

- Wilayah perencanaan selalu lebih luas daripada wilayah pengaturan dikarenakan penetapan dari 2 batasan wilayah pengelolannya (wilayah perencanaan dan wilayah pengaturan) pada suatu program pengelolaan wilayah pesisir, Pemerintah mendapat kewenangan penuh dalam mengeluarkan atau menolak izin kegiatan pembangunan pada pengelolaan wilayah sehari-hari. Oleh karena itu, instansi pengelolaan wilayah pesisir bersama instansi yang mengelola daerah hulu atau laut lepas menjadi penanggungjawab atas kewenangan di luar batas wilayah pengaturan (regulation zone).

- Bisa terjadi perubahan dari batas ke arah darat dari suatu wilayah pesisir

\subsection{Pengembangan Kawasan Pesisir}

Pengembangan kawasan pesisir (pantai utara) dengan melakukan reklamasi pantai, tampaknya kurang memperhatikan kepentingan semua pihak. Hilangnya fungsi sebagai daerah tampungan yang dapat memperbesar aliran permukaan diakibatkan dari terdapatnya reklamasi pantai pada daerah rawa-rawa di wilayah pesisir. Aliran sungai semakin lambat diakibatkan dari adanya reklamasi, arti dari mengurangi luas tampang basah sungai di muara yaitu dengan pertambahan sedimentasi di muara bertambah akibatnya yaitu dari kecepatan berkurang. Pembendungan yang cukup signifikan akan meningkatkan frekuensi banjir karena kapasitas tampang sungai yang terlampaui oleh debit sungai, hal ini diakibatkan dari pendangkalan muara akan menimbulkan efek. Potensi banjr yang terjadi akan semakin besar dikarenakan penggunaan air tanah yang berlebihan menyebabkan penurunan permukaan tanah (land 
subsidence). Belum lagi dengan membuat suatu tambahan daratan yang menjorok ke laut, hal ini akan mempengaruhi adanya perubahan sirkulasi dan gerusan ombak, pada gilirannya akan terjadi abrasi pada kawasan di kanan-kiri lahan yang direklamasi (Ridlo dan Eppy, 2017).

Disamping itu permasalahan lingkungan merupakan masalah yang paling sering ditemui pada kawasan waterfront. Muara-muara sungai akan menjadi pangkalan sampah dan limbah yang berbahaya baik pada kehidupan laut maupun kehidupan darat. Di banyak negara berkembang permasalahan pengelolaan limbah sebelum masuk sungai merupakan kendala besar. Pemerintah perlu mengeluarkan dana lebih untuk mengatasi timbunan sampah di wilayah perairan. Endapan lumpur sungai yang tidak dapat dikendalikan dapat pula menyebabkan banjir ditambah dengan rob akibat intrusi air laut. Hal ini disebabkan oleh penempatan bangunan yang berlebihan sehingga mengurangi daya serap air. Artinya bahwa perlu diperhitungkan secara cermat terjadinya perubahan lingkungan, jangan sekedar membuat rencana-rencana pembangunan kawasan pesisir yang hanya menciptakan mimpimimpi indah sebagai waterfront-city dengan lot-lot/kapling-kapling yang siap dijual. Padahal infrastruktur belum ada dan pasti membutuhkan investasi yang sangat besar.

Tampaknya Pemerintah Kota Semarang lebih suka mengubah kawasan pesisir pantai (waterfrontcity) yang hanya berorientasi pada sisi bisnis. Kawasan tersebut menjadi sebuah lahan bisnis dengan menempatkan bangunan bernilai ekonomis tinggi, dan lebih lanjut sentrasentra bisnis akan bermunculan. Ada hal yang terlupakan oleh Pemerintah Kota Semarang bahwa aktivitas masyarakat yang tinggal di Semarang Utara dominasinya adalah sektor perikanan dan kelautan. Oleh karenanya, dalam pembangunan kawasan pesisir dan pantai harus tetap mempertahankan aktivitas masyarakatnya. Jangan sampai pengembangan kawasan pesisir dan pantai justru mempengaruhi masyarakat (nelayan) setempat merelakan tanahnya untuk dijual. Kejadian selanjutnya dapat ditebak, tumbuhnya bangunan baru dengan nilai ekonomis yang lebih besar. Maka kehidupan tradisional berubah menjadi kehidupan modern dan hal itu menyebabkan terjadinya perubahan ciri kawasan. Masyarakat sudah tergeser, mereka tidak lagi mengayuh sampan dan menjaringkan jala. Orientasi masyarakatnya sudah berubah ke sektor perkotaan.

Pemerintah Kota Semarang mestinya perlu mengarahkan bahwa kawasan pesisir ini sebagai ruang publik, tidak sekedar suatu proses dagang semata dengan tujuan profit oriented. Namun tetap memberikan akses ke ruang bebas dari pantai yang dapat dimasuki oleh 
siapapun. Ruang bebas dapat diwujudkan dengan memberikan jarak bebas tertentu dari garis pantai.

Dan yang lebih penting lagi adalah lestarinya kehidupan dan aktivitas masyarakat pesisir dan pantai. Kawasan pesisir dan pantai adalah area publik yang memberikan pengaruh baik manfaat atau keuntungan untuk masyarakat sebagian besar dalam pendidikan tentang hidup bersosialisasi, kemaritiman, budaya, kaitan sejarah dan warisan yang ada di lingkungan kawasan tersebut. Bahkan kawasan waterfront tersebut dapat menjadi sumber inspirasi seseorang dalam mengembangkan pengetahuannya. Oleh karena itu, pemanfaatan waterfront yang tidak memperhatikan kehidupan dan aktivitas masyarakatnya justru akan menurunkan nilai-nilai yang ada dalam diri manusia.

\subsection{Proses Padu Serasi}

Pada wilayah pesisir sering terjadi tumpang tindih perencanaan, khususnya di wilayah kecamatan pesisir. Pemerintah perlu mengatur mekanisme pemanfaatan sumberdaya pesisir, tidak saja sebagai state property, tetapi juga mengakui common property. Jangan sampai ijin diberikan kepada sasaran yang salah, yang hanya akan mengeksploitasi sumberdaya yang ada dengan tujuan "profit oriented" saja, tanpa ada niatan untuk melestarikannya, sehingga dalam pemanfaatan sumberdaya pesisir terjadi the tragedy of commons. Tetapi di kawasan pesisir ini sudah ada masyarakat yang sudah turun temurun, bahkan mungkin sudah ada sejak sebelum negara ini diproklamirkan, sehingga mereka juga berhak dan patut untuk diperhatikan dan diberikan konsesi pengelolaan.

Oleh karenanya, perpaduan rencana tata ruang darat dan rencana zonasi pesisir sangat diperlukan. Dalam proses penyusunan RTRW dan rencana zonasi (RZ) wilayah pesisir, perlu dilakukan proses padu serasi melalui badan yang terkait.

Perpaduan rencana tata ruang darat dan rencana zonasi (RZ) pesisir merupakan satu kesatuan rencana tata ruang wilayah yang diharapkan dapat ditetapkan dalam satu Peraturan Daerah (Perda) baik provinsi maupun kabupaten/kota. Momentum kearah keterpaduan perencanaan tersebut dilandasi dengan Undang-undang No. 26 tahun 2007 (tentang Penataan Ruang) dan UU No. 27 tahun 2007 (tentang Pengelolaan Pesisir dan Pulau-pulau Kecil) serta penyusunan struktur dan pola ruang pesisir dan laut. Jika Pemerintah Daerah telah menetapkan Perda Rencana Tata Ruang Wilayah (RTRW), maka Rencana Zonasi perlu diperdakan secara tersendiri. Rencana Zonasi yang telah diperdakan menjadi landasan bagi 
Daerah untuk menerbitkan Hak Pengusahaan Perairan Pesisir (HP3). HP3 tidak boleh diterbitkan di kawasan konservasi, alur laut, pantai umum yang telah digunakan penduduk secara turun temurun. HP3 ini diharapkan dapat menjadi instrumen ekonomi untuk mendorong investasi di wilayah pesisir.

Dengan adanya perpaduan rencana tata ruang darat dan rencana zonasi (RZ) pesisir, diharapkan konflik kepentingan dan alokasi ruang pesisir dapat diselesaikan di daerah, sebelum diproses lebih lanjut ke Badan Koordinasi Penataan Ruang Nasional.

Berlandaskan Undang-undang No. 26 tahun 2007 (tentang Penataan Ruang) dan UU No. 27 tahun 2007 (tentang Pengelolaan Pesisir dan Pulau-pulau Kecil), jika realisasi pembangunan ditemukan pelanggaran terhadap RTRW/Rencana Zonasi, maka akan membawa konsekuensi hukum, tidak hanya bagi pihak yang memanfaatkan, tetapi juga bagi aparatur yang memberikan izin pemanfaatan ruang yang tidak sesuai dengan RTRW/RZ.

\section{KESIMPULAN DAN SARAN}

\subsection{Kesimpulan}

- Pengembangan kawasan pantai hendaknya mempertimbangkan bahwa pemanfaatan potensi yang dimiliki untuk mensejahterakan masyarakat atau kawasan di sekitarnya, dapat diakses oleh siapa pun, sebagai bagian dari ruang terbuka publik kota, sekaligus tetap menjaga kelestarian ekosistem kawasan pantai.

- Pemerintah Kota Semarang hendaknya menyiapkan Rencana Tata Bangunan dan Lingkungan (RTBL) Kawasan Pesisir-Pantai yang diperhitungkan secara ekologis dan sustainable. RTBL juga perlu dikaji secara komprehensif, sesuai dengan kaidah-kaidah secara planologis, mengakomodir semua kepentingan, termasuk adanya kemudahan bagi publik dalam mengakses dan menikmati kawasan pesisir dan pantai.

- Pengembangan kawasan pesisir-pantai akan meliputi pengembangan kawasan budidaya dan pengembangan kawasan perlindungan ekosistem pada kawasan lindung.

- Memberikan informasi dan sosialisasi kepada stakeholder (masyarakat, pengembang (investor) maupun aparat kelurahan dan kecamatan) yang terlibat dalam pengembangan kawasan pesisir-pantai), mengenai potensi dari adanya sumberdaya alam (hayati dan non hayati), agar dapat dikelola dan dimanfaatkan secara terpadu dan berkelanjutan. 
- Untuk menghidari dampak negatif yang mungkin terjadi, diharapkan adanya pengawasan dan pemantauan lingkungan pesisir dan pantai secara kontinyu.

- Pemerintah harus bersikap realistis dalam mengukur kemampuan dan potensi suatu kawasan, sehingga rencana di atas, secara ekonomi feasible, secara sosial adaptable, secara kebutuhan realible dan yang paling penting yaitu sustainable.

- Terciptanya keseimbangan dan keharmonisan dalam pemanfaatan kawasan pesisir dan pantai, terlestarikannya lingkungan secara berkelanjutan, pada gilirannya taraf hidup dan kesejahteraan masyarakat meningkat.

\subsection{Saran}

Melihat kompleksitas ekosistim dan adanya berbagai kepentingan oleh stakeholder di kawasan pesisir, maka dalam pelaksanaan pengembangan kawasan pesisir perlu adanya dukungan dan keterpaduan yang melibatkan sumber daya manusia dan para ahli yang multi disiplin ilmu. Multi disiplin ilmu ini penting antara lain: ilmu geologi, ilmu geografi, ilmu geodesi, ilmu ekologi, ilmu sosial, ilmu ekonomi dan ilmu keteknikan maupun ilmu hukum yang berkitan dengan pengelolaan kawasan pesisir. Dengan melibatkan sumber daya manusia dan para ahli yang multi disiplin ilmu, diharapkan dapat memberikan informasi dan kajian yang utuh untuk suatu kawasan pesisir yang dapat digunakan oleh urban manager maupun decision maker dalam membuat suatu keputusan dan kebijakan.

\section{DAFTAR PUSTAKA}

Beatley, T., Brower, D., \& Schwab, A. K. (1994). An introduction to coastal zone management. Island Press.

Beatley, T., \& Manning, K. (1997). The ecology of place: Planning for environment, economy, and community. Island Press.

Cathers, L. D., \& Brahtz, J. F. (1972). Coastal zone management: multiple use with conservation.

Post, J. C., \& Lundin, C. G. (Eds.). (1996). Guidelines for integrated coastal zone management. The World Bank.

Costanza, R., d'Arge, R., De Groot, R., Farber, S., Grasso, M., Hannon, B., \& Raskin, R. G. (1997). The value of the world's ecosystem services and natural capital. nature, 387(6630), 253-260. 
Dahuri, R., Rais, J., Ginting, S. P., \& Sitepu, M. J. (2001). Pengelolaan sumberdaya pesisir dan lautan secara terpadu. Pradnya Paramita. Jakarta.

Hinrichsen, D. (1999). Coastal waters of the world: trends, threats, and strategies. Island Press.

Ridlo, M. A., \& Yuliani, E. (2018). Mengembangkan Kawasan Pesisir Pantai Kota Semarang Sebagai Ruang Publik. Jurnal Geografi: Media Informasi Pengembangan dan Profesi Kegeografian, 15(1), 86-98.

Ridlo, M. A. \& Yuliani, E. (2017). Rekonsiliasi Kehidupan Sosial, Ekonomi Dan Budaya Masyarakat Di Permukiman Kawasan Pesisir Kota Semarang, Penelitian Unggulan Perguruan Tinggi (PUPT)

Ridlo, M. A. (2016). Mengupas Problema Kota Semarang Metropolitan. Deepublish. Yogyakarta.

Ridlo, M. A. (2015). Konsep Penanganan Bencana Longsor dan Banjir di Kota Semarang, Prosiding Membangun Kemandirian Industrialisasi dan Teknologi Berbasis Riset Kebencanaan Indonesia, Universitas Gadjah Mada, Yogyakarta.

Ridlo, M. A. \& Asfari, G. D. (2014). Model Penataan Sumber daya Pesisir di Kawasan Pesisir Kota Semarang, Penelitian Hibah Bersaing

Ridlo, M. A. (2011). Perumahan dan Permukiman di Perkotaan - Fakta, Anaisis dan Solusi, Cetakan Pertama, UNISSULA PRESS.

Ridlo, M. A. (2002). Karakteristik Kemiskinan Perkotaan pada Permukiman Kumuh dan Liar di Kota Semarang, Thesis Magister Perencanaan Wilayah dan Kota - Universitas Diponegoro.

Ridlo, M. A. (2001). Kemiskinan di Perkotaan. Semarang: Penerbit Unissula. 